Sains Malaysiana 47(7)(2018): 1579-1583

http://dx.doi.org/10.17576/jsm-2018-4707-28

\title{
Electrical Properties and AC Susceptibility of CdTe Added $\mathrm{Tl}_{2} \mathrm{Ba}_{2} \mathrm{CaCu}_{2} \mathrm{O}_{8-\delta}$ Superconductor
}

(Sifat Elektrik dan Kerentanan AU Superkonduktor $\mathrm{Tl}_{2} \mathrm{Ba}_{2} \mathrm{CaCu}_{2} \mathrm{O}_{8-\delta}$ Ditambah dengan $\mathrm{CdTe}$ )

\author{
K. MUHAMMAD-AiZAT \& R. ABD-SHUKOR*
}

\begin{abstract}
Information on semiconductor/superconductor interface is important in fabricating devices of such hybrid systems. In

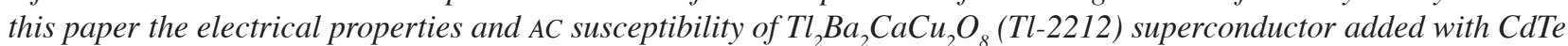

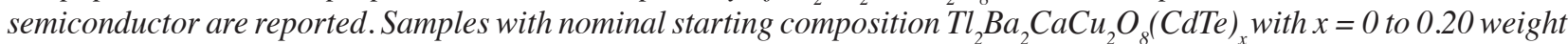
percent (wt. \%) have been prepared by the solid-state reaction method. X-ray diffraction patterns showed essentially the $\mathrm{Tl}-2212$ phase with presence of impurities ( $\mathrm{CuO}$ and $\mathrm{Tl}_{2} \mathrm{Ba}_{2} \mathrm{CuO}$ ) for $\mathrm{x} \geq 0.05 \mathrm{wt} . \%$ but did not change the $\mathrm{Tl}-2212$ structure which is tetragonal with lattice parameter $a=b \neq c$. The critical onset temperature, $T_{c-o n s e t}$ for all samples was between 104 and $108 \mathrm{~K}$ while the critical zero resistance temperature, $T_{c \text {-zero }}$ was from 93 to $95 \mathrm{~K}$. The superconducting transition determined by AC susceptibility measurement showed $T_{c}$, between 101 and $103 \mathrm{~K}$. The peak temperature, $T_{p}$ of the imaginary part of the susceptibility $\chi$ " decreased for $x=0.05$ and then increased for $x>0.05$. This indicated that the superconducting grains were strongly coupled for $x>0.05$ as a result of CdTe addition. The intergrain critical current density, $J_{c}$ at $T_{p}$ for the $x=0.2$ sample $J_{c}\left(T_{p}=95 \mathrm{~K}\right)=23 \mathrm{~A} \mathrm{~cm}^{-2}$ was the highest among all samples. This sample also showed the highest $T_{p}$ indicating CdTe improved the flux pinning of the Tl-2212 phase. This result can be useful in the fabrication of semiconductor/superconductor (Tl-2212) hybrid devices.
\end{abstract}

Keywords: Intergrain coupling; superconductor/semiconductor interface; $\mathrm{Tl}_{2} \mathrm{Ba}_{2} \mathrm{CaCu}_{2} \mathrm{O}_{8-\delta}$

ABSTRAK

Maklumat tentang antara muka semikonduktor/superkonduktor adalah penting dalam pembuatan peranti sistem hibrid. Kajian ini melaporkan sifat elektrik dan kerentanan arus ulang alik (AU) superkonduktor $\mathrm{Tl}_{2} \mathrm{Ba}_{2} \mathrm{CaCu}_{2} \mathrm{O}_{8}(\mathrm{Tl}-2212)$ ditambah dengan semikonduktor $\mathrm{CdTe}$. Sampel $\mathrm{Tl}_{2} \mathrm{Ba}_{2} \mathrm{CaCu}_{2} \mathrm{O}_{8}(\mathrm{CdTe})_{x}$ dengan komposisi penambahan $x=0$ hingga 0.20 peratus berat (\% bt.) telah disediakan dengan menggunakan kaedah tindak balas keadaan pepejal. Corak pembelauan sinar-X menunjukkan kehadiran fasa Tl-2212 dengan kewujudan bendasing ( $\mathrm{CuO}$ dan $\mathrm{Tl}_{2} \mathrm{Ba}_{2} \mathrm{CuO}_{6}$ ) bagi $x \geq 0.05 \% \mathrm{bt}$. tetapi tidak berubah fasa dan struktur asal sistem Tl-2212 iaitu struktur tetragonal dengan parameter kekisi $a=b \neq$ c. Suhu genting mula, $T_{c-m u l a}$ sampel adalah antara 104 hingga $108 \mathrm{~K}$ manakala suhu genting sifar, $T_{c-s i f a r}$ adalah antara 93 hingga $95 \mathrm{~K}$. Peralihan kesuperkonduksian menggunakan pengukuran kerentanan AU menunjukkan julat suhu $T_{c c}$ antara 101 hingga $103 \mathrm{~K}$. Suhu puncak, $T_{p}$ bahagian khayalan kerentanan, $\chi$ ” berkurang untuk $x=0.05$ dan meningkat untuk $x>0.05$. Ini menunjukkan bahawa butiran superkonduktor bergandingan secara kuat untuk $x>0.05$ disebabkan penambahan CdTe. Ketumpatan arus genting antara butiran, $J_{c}$ pada $T_{p}$ untuk sampel $x=0.20, J_{c}\left(T_{p}=95 \mathrm{~K}\right)=23 \mathrm{~A}$ $\mathrm{cm}^{-2}$ merupakan nilai tertinggi antara kesemua sampel. Sampel ini juga mencatatkan $T_{p}$ tertinggi yang menunjukkan CdTe menguatkan pengepinan fluks bagi fasa Tl-2212. Keputusan kajian ini berguna untuk penghasilan peranti hibrid semikonduktor/superkonduktor (Tl-2212).

Kata kunci: Antara muka superkonduktor/semikonduktor; gandingan antara butiran; $\mathrm{Tl}_{2} \mathrm{Ba}_{2} \mathrm{CaCu}_{2} \mathrm{O}_{8-\delta}$

\section{INTRODUCTION}

The Tl-based cuprate superconductors have been of interest due to the relatively high transition temperatures. The effects of various elements and compounds on $\mathrm{Tl}_{2} \mathrm{Ba}_{2} \mathrm{CaCu}_{2} \mathrm{O}_{8}$ (T1-2212) and other cuprate high temperature superconductors (HTSC) have been studied in order to improve the superconducting properties. This includes the effect of magnetic and non-magnetic particles, complex oxides, nanoparticles and various compounds on HTSC (Akimov et al. 2006; Annas et al. 2016; Awad et al. 2016; Gerashchenko et al. 1998; Hassan et al. 2016; Ji et al. 2013; Mumtaz et al. 2016). The optimal method to prepare the Tl-2212 phase has also been reported (AbdShukor 1993).

The interface between semiconductor and superconductor is of interest from the fundamental as well as application point of view. Information on the transport properties at the interface can be useful in the fabrication of semiconductor/superconductor-based devices. The hetero-epitaxial growth of multilayer structures of HTSC and its integration with other technologies will help in the realization of advanced cryogenic-based devices. 
The growth of semiconductor/superconductor system in $\mathrm{Hg}_{1-x} \mathrm{Cd}_{x} \mathrm{Te} / \mathrm{YBa}_{2} \mathrm{Cu}_{3} \mathrm{O}_{7-\delta}$ (Cheung et al. 1991) and $\mathrm{Tl}_{2} \mathrm{Ba}_{2} \mathrm{CaCu}_{2} \mathrm{O}_{8} / \mathrm{CdS}$ hetero-structure have been reported (Shirage et al. 2006). It was shown that $\mathrm{HgCdTe} /$ $\mathrm{YBa}_{2} \mathrm{Cu}_{3} \mathrm{O}_{7-\delta}$ structure could be grown at low temperature where the quality of both semiconductor and superconductor is preserved. $\mathrm{CdS}$ improved the critical current density of $\mathrm{Tl}_{2} \mathrm{Ba}_{2} \mathrm{Ca}_{2} \mathrm{Cu}_{3} \mathrm{O}_{10}$ superconductor (Shirage et al. 2006). Nanosized $\mathrm{CeO}_{2}$ was also found to improve the critical current density of Tl-2212 thin films (Ji et al. 2013). The Tl-2212 and Tl-2223 phase was formed when $\mathrm{B}_{2} \mathrm{O}_{3}$ was added during the first and second heating stage, respectively (Cavdar et al. 2003). The superconducting transition temperature of Tl-2212 was found to exhibit a parabolic behavior with a maximum of $114 \mathrm{~K}$ around 7 GPa (Jian-Bo et al. 2015).

There has been some works on semiconductor/ superconductor interface (Ji et al. 2013; Shirage et al. 2006). CdTe semiconductor has many applications in electronic devices and the unique nature of $\mathrm{CdTe}$ semiconductor makes it interesting to be incorporated into $\mathrm{Tl}_{2} \mathrm{Ba}_{2} \mathrm{CaCu}_{2} \mathrm{O}_{8}$. In this paper, we report on the $\mathrm{AC}$ susceptibility and superconducting properties of $\mathrm{Tl}_{2} \mathrm{Ba}_{2} \mathrm{CaCu}_{2} \mathrm{O}_{8}(\mathrm{CdTe})_{x}$ for $x=0$ to $0.2 \mathrm{wt}$. $\%$. The $\mathrm{X}$-ray powder diffraction results and DC electrical resistance versus temperature measurements together with Field Emission Scanning Electron Microscope (FESEM) observations are presented. AC susceptibility measurements were also performed to determine the transition temperature and intergrain critical current density.

\section{MATERIALS AND METHODS}

The samples were prepared by the solid-state reaction method. A precursor was prepared by mixing appropriate amounts of high purity (99.9+\%) powders of $\mathrm{BaO}, \mathrm{CaO}$ and $\mathrm{CuO}$ in an agate mortar to obtain a homogeneous mixture. The powders were heated for $48 \mathrm{~h}$ at $900^{\circ} \mathrm{C}$ with several intermittent grindings and furnace cooled. $\mathrm{Tl}_{2} \mathrm{O}_{3}$ and $\mathrm{CdTe}$ were added to the precursor powders and then pressed into pellets with approximately $13 \mathrm{~mm}$ diameter and $2 \mathrm{~mm}$ thickness. Excess $10 \% \mathrm{Tl}_{2} \mathrm{O}_{3}$ was added to compensate for thallium lost during the heating process. The pellets were heated at $890^{\circ} \mathrm{C}$ for $4 \mathrm{~min}$ in oxygen flow followed by furnace cooling to room temperature.

The samples were analyzed by X-ray powder diffraction method using Bruker D8 Advance diffractometer with $\mathrm{CuK}_{\alpha}$ source. The DC electrical resistance versus temperature measurements were carried out using four-point probe method with silver paste contacts in conjunction with a closed cycle refrigerator from CTI Cryogenics Model 22 and a temperature controller from Lake Shore Model 330. A constant current source between 1 and $100 \mathrm{~mA}$ was used throughout the measurements. Field Emission Scanning Electron Microscope (FESEM) micrographs were recorded using a Zeiss Supra 55 vP scanning electron microscope. An AC susceptometer from Cryo Industry model number
REF-1808-ACS was used to determine the susceptibility from $30 \mathrm{~K}$ to $120 \mathrm{~K}$. The samples were cut into bar shape for the AC susceptibility measurements. The frequency of the AC signal was $295 \mathrm{~Hz}$ and the applied magnetic field was $H=5$ Oe. The critical current density $J_{c}$ at the peak temperature $T_{\mathrm{p}}$ of $\chi$ " was calculated using the Bean model (Bean 1964) with formula $J_{\mathrm{c}}\left(T_{\mathrm{p}}\right)=H /(l w)^{1 / 2}$ where $H$ is the applied magnetic field, $l$ and $w$ are the dimensions of the cross section of the bar-shaped sample. $T_{\mathrm{p}}$ is the peak temperature of $\chi$ " of the AC susceptibility.

\section{RESULTS AND DISCUSSION}

The X-ray diffraction patterns of $\mathrm{Tl}_{2} \mathrm{Ba}_{2} \mathrm{CaCu}_{2} \mathrm{O}_{8}(\mathrm{CdTe})_{x}$ with $x=0,0.05,0.1,0.15,0.2$ are shown in Figure 1 . The diffraction peaks indicated that the $x=0$ sample consisted of essentially the T1-2212 phase with the tetragonal structure and space group $14 / \mathrm{mmm}$ and lattice parameter $a=b \neq c$. No significant changes in the lattice parameters of the Tl-2212 phase were observed as CdTe
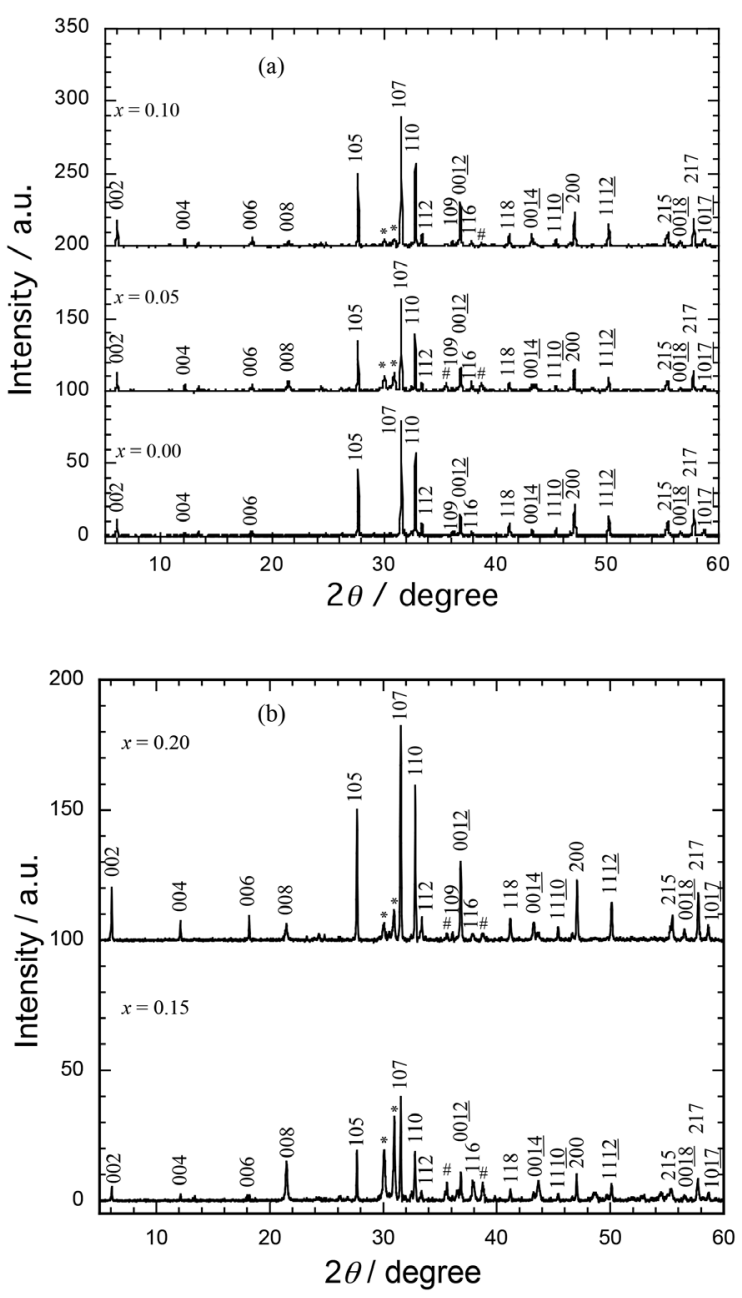

FIGURE 1. X-ray powder diffraction patterns for $\mathrm{Tl}_{2} \mathrm{Ba}_{2} \mathrm{CaCu}_{2} \mathrm{O}_{8}(\mathrm{CdTe})_{x}$ (a) $x=0,0.05$ and 0.10 and (b) $x=0.15$ and 0.20 . (\#) and (*) indicate $\mathrm{CuO}$ and $\mathrm{Tl}_{2} \mathrm{Ba}_{2} \mathrm{CuO}_{6}$, respectively 
was added. With CdTe addition, minor impurities i.e. $\mathrm{CuO}$ and $\mathrm{Tl}_{2} \mathrm{Ba}_{2} \mathrm{CuO}_{6}(\mathrm{Tl}-2201)$ peaks were observed. No peaks from $\mathrm{CdTe}, \mathrm{Cd}$ and $\mathrm{Te}$ compounds were observed indicating both $\mathrm{Cd}$ and $\mathrm{Te}$ may have been incorporated into the Tl-2212 phase. Previous works on $\mathrm{CdO}$ and $\mathrm{CdTe}$ addition in $\mathrm{YBa}_{2} \mathrm{Cu}_{3} \mathrm{O}_{7}$ showed that these compounds exist separately and did not enter the $\mathrm{YBa}_{2} \mathrm{Cu}_{3} \mathrm{O}_{7}$ crystal structure (Iguchi et al. 1988; Nur-Akasyah et al. 2017).

Figure 2(a) and 2(b) shows the FESEM micrographs for $x=0$ and 0.10 samples, respectively. The $x=0$ micrograph showed well defined grain boundaries. The addition of CdTe resulted in a smaller irregular grain size of less than $1 \mu \mathrm{m}$ (Figure 2(b)). Figure 3 shows the EDX spectrum and weight percentage of each element for $x=$ 0.10 wt. \% sample. The spectrum showed a homogeneous distribution of Ce and $\mathrm{Te}$ in the Tl-2212 matrix.

The electrical resistance versus temperature curves are shown in Figure 4. The onset transition temperature, $T_{\text {c-onset }}$ is defined as the temperature where there is a sudden drop in resistance and can be obtained from the

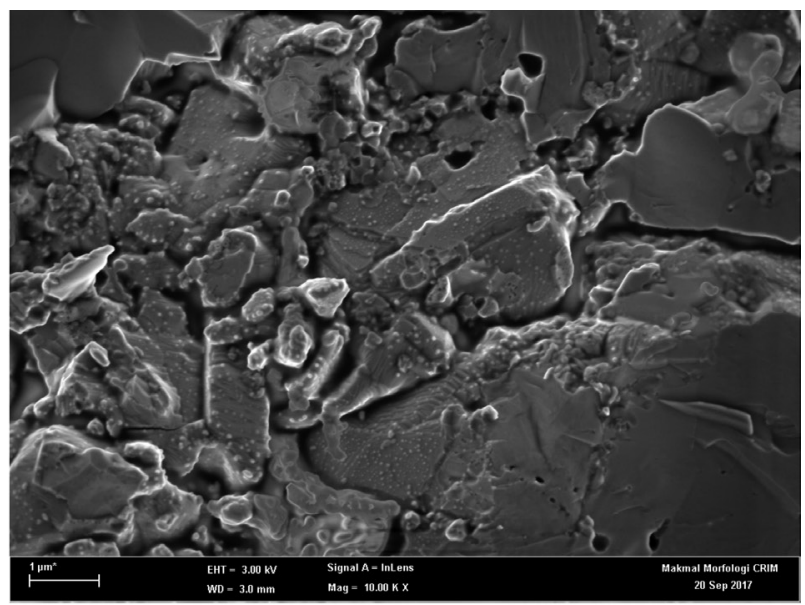

a) $x=0$

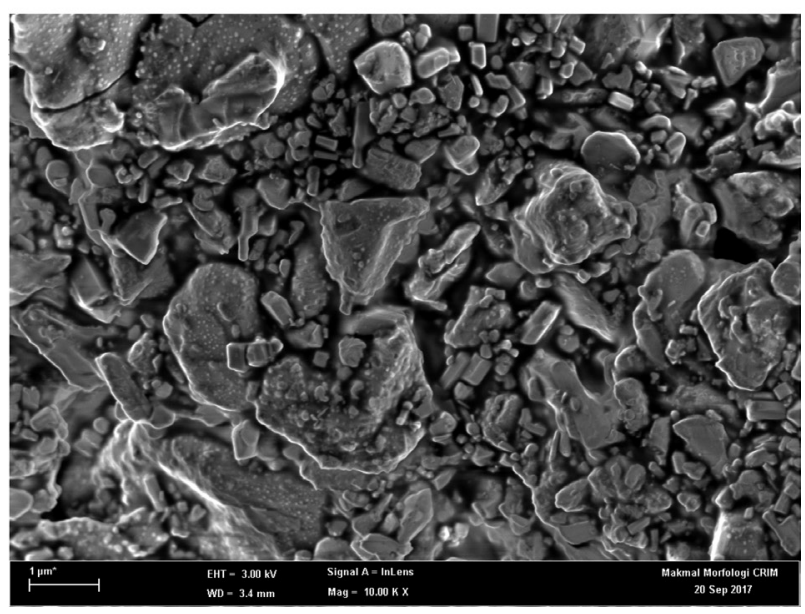

b) $x=0.1$

FIGURE 2. Scanning electron micrographs for $\mathrm{Tl}_{2} \mathrm{Ba}_{2} \mathrm{CaCu}_{2} \mathrm{O}_{8}(\mathrm{CdTe})_{x}$ (a) $x=0$ and (b) $x=0.10$ wt. $\%$ crossing point of the linear fit of the highest slope and the metallic high temperature part of the $\rho(\mathrm{T})$ curve for each sample. The zero-resistance temperature, $T_{\text {c-zero }}$ is the temperature where the resistance drops to zero and can be estimated from the extrapolation of the linear part of the resistance to the temperature axis. $T_{\text {c-onset }}$ for all samples

(a)

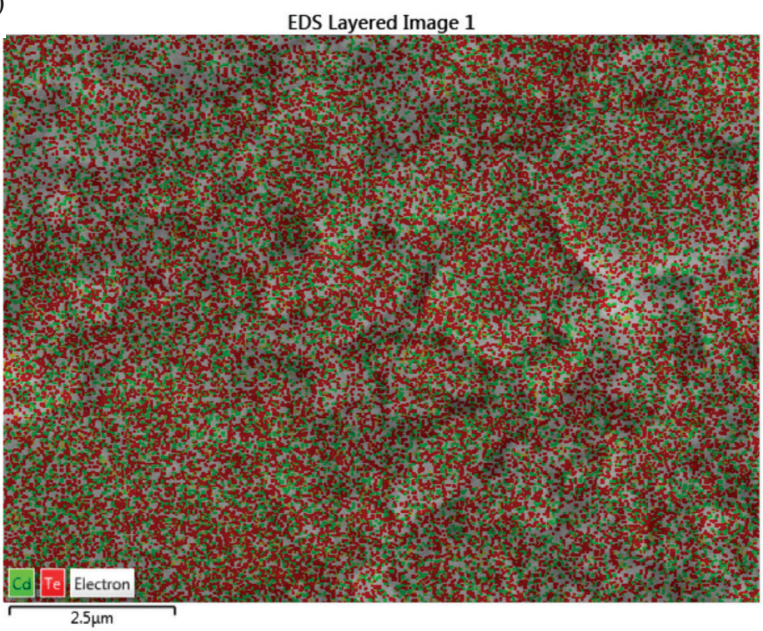

(b)

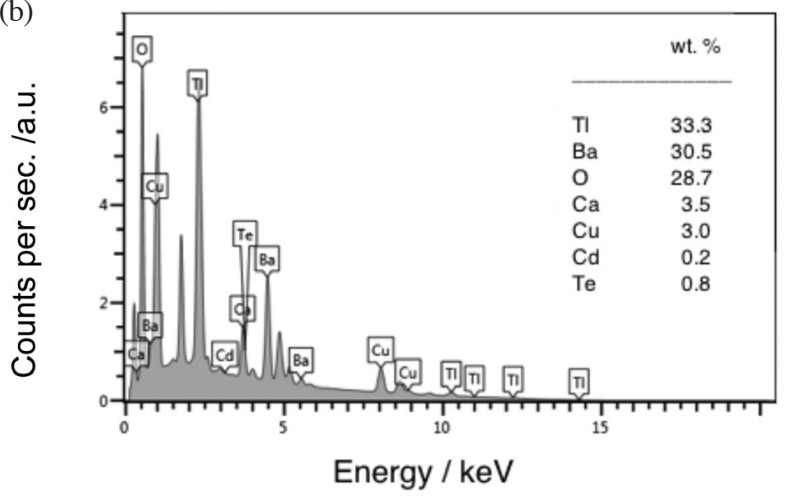

FIGURE 3. (a) Distribution of Cd and Te and (b) EDX spectrum and weight percentage (insert) of each element for the $x=0.10 \mathrm{wt}$. \% sample

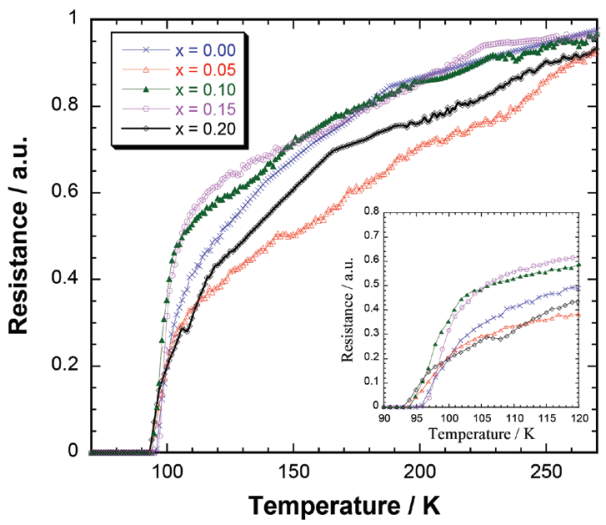

FIGURE 4. Electrical resistance versus temperature of $\mathrm{Tl}_{2} \mathrm{Ba}_{2} \mathrm{CaCu}_{2} \mathrm{O}_{8}(\mathrm{CdTe})_{x}$ for $x=0,0.05,0.10,0.15$ and 0.20 
was between 104 and $108 \mathrm{~K}$. The highest $T_{\text {c-onset }}$ was 108 $\mathrm{K}$ for the non-added Tl-2212. $T_{\text {c-zero }}$ was between 93 and $95 \mathrm{~K}$. The normal state resistance versus temperature curves showed metallic normal state behaviour for all samples. This is despite the significant change in the grain boundaries as a result of CdTe addition. The electrical resistivity at room temperature, $\rho_{297 \mathrm{~K}}$ for the non-added sample was around $2.11 \mathrm{~m} \Omega . \mathrm{cm}$. When CdTe was added, the resistivity increased to $13.52 \mathrm{~m} \Omega . \mathrm{cm}$ for the $x=0.20$ wt. \% sample. The increase in the resistivity could be due to the changes in the grain size, which became smaller as CdTe was added. The room temperature resistivity $\rho_{297 \mathrm{~K}}$, $T_{\text {c-onset }}$ and $T_{\text {c-zero }}$ are shown in Table 1.

The transition temperature as measured by AC susceptibility, $T_{c x}$, for all samples was around $101 \mathrm{~K}$ and $103 \mathrm{~K}$ (Figure 5). The sudden decrease in the real part $\chi^{\prime}$ of the complex susceptibility $\left(\chi=\chi^{\prime}+\mathrm{i} \chi^{\prime \prime}\right)$ below the transition temperature indicates diamagnetic shielding and the peak in the imaginary part of the susceptibility, $\chi$ " represents the AC losses. $T_{c x}$, does not change very much with CdTe addition. $T_{c x^{\prime}}, T_{\mathrm{p}}$ and $J_{\mathrm{c}}\left(T_{\mathrm{p}}\right)$ are shown in Table 1. The peak temperature, $T_{\mathrm{p}}$ of the imaginary part of the susceptibility $\chi$ " increased as CdTe was added except for $x=0.05$ wt. $\%$ where $T$ decreased. Upon increase in CdTe content, $T_{\mathrm{p}}$ shifted to higher temperatures due to the strengthening of the pinning forces. At $T_{\mathrm{p}}$, the AC field amplitude is equal to the full flux penetration field. The intergrain critical current density, $J_{\mathrm{c}}$ at $T_{\mathrm{p}}$ for the samples are shown in Table 1 . The $x=0$ sample showed $J_{\mathrm{c}}\left(T_{\mathrm{p}}=90\right.$ $\mathrm{K})=20 \mathrm{~A} \mathrm{~cm}^{-2}$ and for $x=0.2, J_{\mathrm{c}}\left(T_{\mathrm{p}}=95 \mathrm{~K}\right)=23 \mathrm{~A} \mathrm{~cm}^{-2}$. The increase of $T_{\mathrm{p}}$ from $90 \mathrm{~K}$ to $95 \mathrm{~K}$ and increase in $J_{\mathrm{c}}\left(T_{\mathrm{p}}\right)$ showed that CdTe improved the flux pinning capability of the Tl-2212 phase. No CdTe peaks were observed in the XRD pattern. Hence, the increase in the critical current density may be due to the changes in the microstructure as CdTe was added which enhanced the inter-grain coupling.

In conclusion, samples with nominal starting compositions $\mathrm{Tl}_{2} \mathrm{Ba}_{2} \mathrm{CaCu}_{2} \mathrm{O}_{8}(\mathrm{CdTe})_{x}$ with $x=0,0.05$, $0.1,0.15,0.2$ have been prepared. CdTe addition showed the presence of $\mathrm{CuO}$ and $\mathrm{Tl}-2201$ impurity phase but very small change in the transition temperature. $\mathrm{Cd}$ and Te were homogeneously distributed in the samples. The grain size of the samples decreased as CdTe was added. The coupling between grains was strengthened resulting in increase of $T_{\mathrm{p}}$ for $x>0.05 \mathrm{wt} . \%$. These results are useful in the fabrication of semiconductor/superconductor hybrid devices.

\section{ACKNOWLEDGEMENTS}

This research was supported by Universiti Kebangsaan Malaysia under grant number AP-2015-006 and the Ministry of Higher Education, Malaysia under grant number FRGS/1/2017/STG02/UKM/01/1.

TABLE 1. $\rho_{297 \mathrm{~K}}$, lattice parameter $a$, and $c, T_{\text {c-onset }}, T_{\text {c-zero }}, T_{c x}, T_{\mathrm{p}}$ and $J_{\mathrm{c}}\left(T_{\mathrm{p}}\right)$ of $\mathrm{Tl}_{2} \mathrm{Ba}_{2} \mathrm{CaCu}_{2} \mathrm{O}_{8}(\mathrm{CdTe})_{x}$ for $x=0,0.05,0.10,0.15$ and 0.20

\begin{tabular}{ccccccccc}
\hline$x /$ wt. \% & $\rho_{297 \mathrm{~K}} / \mathrm{m} \Omega . \mathrm{cm}$ & $a / \AA$ & $c / \AA$ & $T_{\text {c-onset }} / \mathrm{K}$ & $T_{\text {c-zero }} / \mathrm{K}$ & $T_{\text {cx }} / \mathrm{K}$ & $T_{\mathrm{p}} / \mathrm{K}$ & $J_{\mathrm{c}}\left(T_{\mathrm{p}}\right) / \mathrm{A} \mathrm{cm}{ }^{-2}$ \\
\hline 0.00 & 2.11 & 3.8579 & 29.265 & 108 & 95 & 103 & 90 & 20 \\
0.05 & 3.04 & 3.8594 & 29.231 & 105 & 93 & 101 & 81 & 19 \\
0.10 & 5.01 & 3.8561 & 29.243 & 104 & 94 & 102 & 94 & 19 \\
0.15 & 8.53 & 3.8581 & 29.219 & 105 & 95 & 102 & 90 & 20 \\
0.20 & 13.52 & 3.8565 & 29.265 & 106 & 93 & 102 & 95 & 23 \\
\hline
\end{tabular}

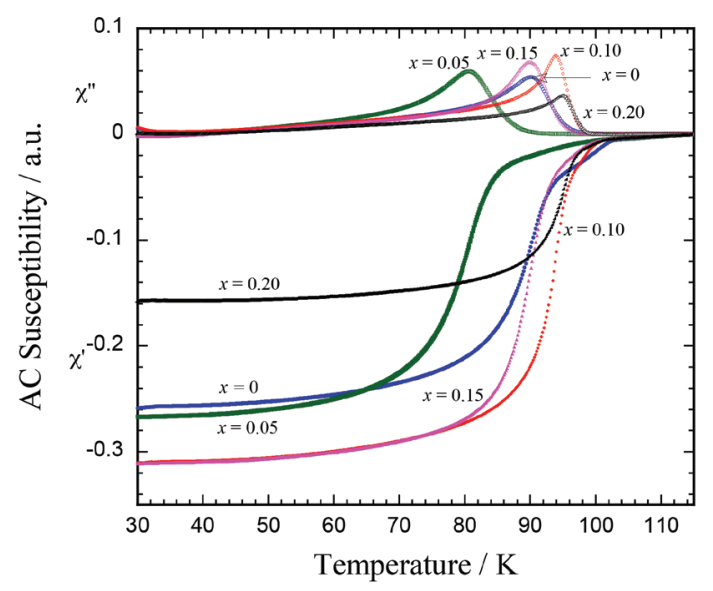

FIGURE 5. AC susceptibility $\left(\chi=\chi\right.$ ' $\left.+\mathrm{i} \chi \chi^{\prime \prime}\right)$ versus temperature of

$\mathrm{Tl}_{2} \mathrm{Ba}_{2} \mathrm{CaCu}_{2} \mathrm{O}_{8}(\mathrm{CdTe})_{x}$ for $x=0,0.05,0.10,0.15$ and 0.20 


\section{REFERENCES}

Abd-Shukor, R. 1993. Optimum preparation of bulk $\mathrm{Tl}_{2} \mathrm{Ba}_{2} \mathrm{CaCu}_{2} \mathrm{O}_{8-\delta}$ (2212) high-temperature superconductor. Journal of Materials Science Letters 12(18): 1428-1429.

Akimov, A.I., Ksenofontov, V., Lebedev, S.A. \& Tkachenka, T.M. 2006. Effect of fluorine and cerium substitutions on the properties of the $\mathrm{Tl}_{2} \mathrm{Ba}_{2} \mathrm{CaCu}_{1.98} \mathrm{Fe}_{0.02} \mathrm{O}_{8}$ superconductor. Physica C: Superconductivity 443(1-2): 29-32.

Al-Sharabi, A., Tajuddin, S.Y., Saffiey, A.D.F.W., Jasman, S., Alwi, H.A., Jumali, M.H. \& Abd-Shukor, R. 2016. Excess conductivity analysis of $\mathrm{PbO}$ nanoparticle added $\mathrm{YBa}_{2} \mathrm{Cu}_{3} \mathrm{O}_{7-\delta}$ superconductor (in Malay). Sains Malaysiana 45(12): 19591968.

Awad, R., Mohammed, N.H., Abou Aly, A.I., Isber, S., Motaweh, H.A., El-Said Bakeer, D. \& Roumié, M. 2016. The effect of nanosized $\mathrm{CoFe}_{2} \mathrm{O}_{4}$ addition on the magnetic properties of $\mathrm{GdBa}_{2} \mathrm{Cu}_{3} \mathrm{O}_{7-\delta}$ using $\mathrm{AC}$ magnetic susceptibility measurements. Journal of Advanced Ceramics 5(1): 93-101.

Bean, C.P. 1964. Magnetization of high-field superconductors. Rev. Mod. Phys. 36(1): 31-39.

Çavdar, S., Aksu, E., Koralay, H., Özkan, H., Gasanly, N.M. \& Ercan, I. 2003. Effect of $\mathrm{B}_{2} \mathrm{O}_{3}$ addition on the formation and properties of Tl-2212 and Tl-2223 superconductors. Physica Status Solidi (a) 199(2): 272-276.

Cheung, J.T., Gergis, I., Kobrin, P., Arias, J. \& DeWames, R.E. 1991. Growth and characterization of a semiconductorsuperconductor heterostructure: $\mathrm{The}_{\mathrm{Hg}} \mathrm{Cd}_{1-x} \mathrm{Te} / \mathrm{YBa}_{2} \mathrm{Cu}_{3} \mathrm{O}_{7-x}$ system. In Advances in Superconductivity III: Proceedings of the 3rd International Symposium on Superconductivity (ISS '90) edited by Kajimura, K. \& Hayakawa, H. Tokyo: Springer. pp. 997-1000.

Gerashchenko, A.P., Verkhovskii, S.V., Mikhalev, K.N., Piskunov, Yu.V., Anan'ev, A.V., Okulova, K.A., Shustov, L.D. \& Yakubovskii, A.Y. 1998. Effect of doping on the behaviour of spin susceptibility of copper-oxygen layers in $\mathrm{Tl}_{2} \mathrm{Ba}_{2} \mathrm{CaCu}_{2} \mathrm{O}_{8-\delta}$. The Physics of Metals and Metallography 86(1): 43-50.

Hassan, B., Alnakhlani, A., Muhammad, A. \& Al-Hajji, M.A. 2016. Influence of $\mathrm{KMnO}_{4}$ substitution on the structural and transport properties of $\mathrm{Tl}_{2} \mathrm{Ba}_{2} \mathrm{Ca}\left(\mathrm{Cu}_{1-x} \mathrm{R}_{x}\right) 2 \mathrm{O}_{\delta+6}$ system. Journal of Physical Science 27(3): 13-24.
Iguchi, I., Sugishita, A., Yanagisawa, M. \& Hosaka, S. 1988. Effect of doping of cadmium oxide to Y-Ba-Cu oxide. Physica C 153-155(2): 892-893.

Ji, L., Gao, X., Ge, D., Xie, W., Wang, P., Zhao, X., Wang, Z., He, M., Zhang, X., Wei, L., Song, F. \& Yan, S. 2013. The influence of $\mathrm{CeO}_{2}$ nano-dots decoration on substrates on flux pinning strength in $\mathrm{Tl}_{2} \mathrm{Ba}_{2} \mathrm{CaCu}_{2} \mathrm{O}_{8}$ IEEE Transactions on Applied Superconductivity 23(3): 8001505.

Mumtaz, M., Liaqat Ali, Shoaib Azeem, Saad Ullah, Hussain, G., Rabbani, M.W.,Abdul Jabbar \& Nadeem, K. 2016. Dielectric properties of $(\mathrm{Zn})_{x} / \mathrm{CuTl}-1223$ nanoparticle-superconductor composites. Journal of Advanced Ceramics 5(2): 159-166.

Nur-Akasyah, J., Nur-Shamimie, N.H. \& Abd-Shukor, R. 2017. Effect of CdTe addition on the electrical properties and AC susceptibility of $\mathrm{YBa}_{2} \mathrm{Cu}_{3} \mathrm{O}_{7-\delta}$ superconductor. Journal of Superconductivity and Novel Magnetism 30(12): 3361-3365.

Shirage, P.M., Shivagan, D.D. \& Pawar, S.H. 2006. Studies on fabrication of $\mathrm{Ag} / \mathrm{Tl}_{2} \mathrm{Ba}_{2} \mathrm{Ca}_{2} \mathrm{Cu}_{3} \mathrm{O}_{10} / \mathrm{CdSe}$ heterostructures with electrochemical technique. Applied Surface Science 253(4): 1836-1842.

Zhang, J.B., Struzhkin, V.V., Yang, W., Mao, H.K., Lin, H.Q., Ma, Y.C., Wang, N.L. \& Chen, X.J. 2015. Effects of pressure and distortion on superconductivity in $\mathrm{Tl}_{2} \mathrm{Ba}_{2} \mathrm{CaCu}_{2} \mathrm{O}_{8+} \boldsymbol{\delta}$. Journal of Physics: Condensed Matter 27(44): 445701.

School of Applied Physics

Faculty of Science and Technology

Universiti Kebangsaan Malaysia

43600 UKM Bangi, Selangor Darul Ehsan

Malaysia

*Corresponding author; email: ras@ukm.edu.my

Received: 12 February 2018

Accepted: 10 March 2018 